\title{
Chemical Compound Characterizations of Patchouli Leaf Extract via GC-MS, LC-QTOF-MS, FTIR, and 1H NMR
}

\author{
Sangeethavani Sundarajan* \\ Faculty of Chemical Engineering and Natural Resources \\ University Malaysia Pahang, \\ Kuantan, Pahang
}

\author{
Nour Hamid Abdurahman \\ Faculty of Chemical Engineering and Natural Resources \\ University Malaysia Pahang, \\ Kuantan, Pahang
}

\begin{abstract}
The demand for patchouli (Pogostemon cablin) essential oil is increasing globally due to its diverse importance in the nutraceutical and pharmaceutical industries. The oil from this plant is an embodiment of different varieties of chemical compounds. It is then important to identify the bioactive compounds in the extracted oil to identify the embedded potential uses of the oil. Hence, this study focused on the characterization of extracted patchouli oil through microwaveassisted hydrodistillation (MAHD) technique using gas chromatography-mass spectrometry (GC-MS), liquid chromatography-mass spectrometry quadrupole time of flight (LC-Q-TOF-MS), nuclear magnetic resonance (NMR), and Fourier transform infrared transmission (FTIR). The obtained results reflected that patchouli leaf oil is endowed with appreciable quantities of non-oxygenated and oxygenated compounds (from GC-MS analysis); 18 tentatively identified phenolic compounds from LC-Q-TOF-MS analysis; several peaks showing the presence of $\mathrm{O}-\mathrm{H}$ stretching in alcohol, $\mathrm{C}=\mathrm{O}$ stretching vibration of carbonyl aldehyde, $\mathrm{C}-\mathrm{H}$ bending stretching of alkane, and $\mathrm{C}=\mathrm{C}$ stretching from aromatic rings were identified from the FTIR analysis. Additionally, the NMR results reflected the abundance of patchouli alcohol in the oil which can contribute to its aroma. Thus, patchouli leaf oil is an important plant endowed with different bioactive compounds.
\end{abstract}

Keywords- Bioactive compounds; Characterization; Microwave-assisted hydrodistillation; Patchouli; Gaschromatography mass spectrometry; Nuclear magnetic resonance

\section{INTRODUCTION}

Patchouli leaves (Pogostemon cablin), a plant belonging to the Lamiaceae family is endowed with essential oil [1]. This plant is usually cultivated in a tropical area particularly southeast Asia [2]. It is an aromatic plant that possesses higher content of essential oil that emanates from its young twigs and leaves. Patchouli oil is a dark orange or brownish colored liquid with a woody, earthy and camphoraceous odour [3]; [1]; [2]. The oil plays an important role in the production of perfumery products such as soaps, cosmetics products and detergents because it possesses a long-lasting odour with fixative properties [4]. Moreover, the patchouli plant is used in traditional Asian medicine as an anti-stress, antiseptic, relieve headaches and fever [5]. Several therapeutic activities of patchouli oil had previously been reported, including antifungal, anti-depressive, anti-bacterial, anti- inflammatory, sedative, febrifuge, and diuretic [4]; [1]

The composition of patchouli essential oil is complex and unique in relation to other essential oils [4]; however, it is distinct due to the presence of sesquiterpenes. Patchoulol is one of the main constituents of this oil and a primary compound accountable for its fragrance [6]. Patchoulol acts as fragrance binder to give long-lasting characteristic for the fragrance as compared to patchoulol, $\alpha$-himachalene, $\alpha-/ \beta-/ \gamma$ patchoulenes, seychellene, and $\alpha$-guaiene [4]; [5]. Moreover, a report had illustrated that patchoulol and $\alpha$-patchoulene are responsible for the oil aroma [4]. Hence, this can increase the trading values of this oil if patchoulol and $\alpha$-patchoulene are present in larger amounts. Conventionally, the essential oil is obtained from a plant matrix through hydrodistillation technique. However, this technique had been reported to take a longer period of extraction, consumed a larger amount of energy with a potential of degenerating the bioactive compounds in the oil. Thus, employing a modern technique of extraction is important to fill up the shortcomings of hydrodistillation technique. The microwave-assisted hydrodistillation extraction technique is being employed due to its fast start-up, efficient heating and faster energy transfer [7]. In addition, characterization of plant extract/oil is essential to tentatively identify the embedded bioactive compounds. Several characterization techniques are being employed to tentatively identify the chemical compounds, these include gas chromatography-mass spectrometry (GC-MS), gas chromatography (GC), liquid chromatography-mass spectrometry quadrupole time of flight (LC-Q-TOF-MS), Fourier transform infrared transmission (FTIR), nuclear magnetic resonance (NMR), and among others.

Although, the bioactive compounds in the patchouli oil had previously been reported [5]; [8], however, comprehensive tentative characterization using gas chromatography-mass spectrometry (GC-MS), liquid chromatography-mass spectrometry quadrupole time of flight (LC-Q-TOF-MS), nuclear magnetic resonance (NMR), and Fourier transform infrared transmission (FTIR) is yet to be reported. Thus, this study focuses on the characterization of oil from patchouli leaves oil to disclose the embedded bioactive compounds.

\section{MATERIALS AND METHODS}

\section{A. Raw material and chemicals}

Dried samples (patchouli leaves) were obtained from Gaya Naturals company, Tawau, Sabah. The dry leaves were separated from stems and further dried at room temperature for several days. Then, the patchouli leaves were blended into powder form. Anhydrous sodium sulphate and 
dichloromethane utilized in this study were obtained Faculty of Chemical and Natural Resources Engineering laboratory.

\section{B. The procedure of essential oil extraction using MAHD}

A modified domestic microwave extractor comprising power and time control was used to extract oil from patchouli leaves. Fig. 1 shows the set up for the MAHD extractor for this study. A $30 \mathrm{~g}$ of patchouli powder was mixed with 180 $\mathrm{mL}$ of distilled water in a round-bottomed glass chamber. The microwave was operated at $400 \mathrm{~W}$ for $1 \mathrm{~h}$. After $1 \mathrm{~h}$, the hydrosol (water + essential oil) was collected from the Clevenger. Then, the hydrosol was placed in a separating funnel by adding few drops of dichloromethane to separate the essential oil from water. Thereafter, anhydrous sodium sulphate was added to eliminate any trace of water in the extracted oil. The obtained oil was then stored in a vial at $-4^{0}$ C for further analysis. The experiment was repeated for 240 , 300,360 , and $420 \mathrm{~mL}$ of distilled water.

\section{Liquid chromatography-mass spectrometry (LC-Q-TOF- MS) analysis}

The chemical constituents in the patchouli essential oil were identified using LC-Q-TOF- MS (Waters, USA). LC-QTOF-MS has higher sensitivity and selectivity in characterizing and identifying the chemical compounds in the extracted oil of patchouli leaf when compared with other characterization methods. The patchouli oil was diluted using analytical grade ethanol to prepare a concentration of 100 $\mathrm{mg} / \mathrm{mL}$. Then, the concentration of the oil is further re-diluted to obtain $20 \mathrm{ppm}$ prior to injection into the mass spectrometer. The QTOF-MS instrument was operated under the following conditions viz; desolvation flow rate $(800 \mathrm{~L} / \mathrm{h})$, desolvation temperature $\left(550^{\circ} \mathrm{C}\right)$, operation mode (+ve and ve mode), scan time ( $0.200 \mathrm{~s}$ to $4.00 \mathrm{~min})$, ms mode (high definition), collision energy interval (4.00-45.00 eV), and scanning range $(100-1000 \mathrm{~m} / \mathrm{z})$.

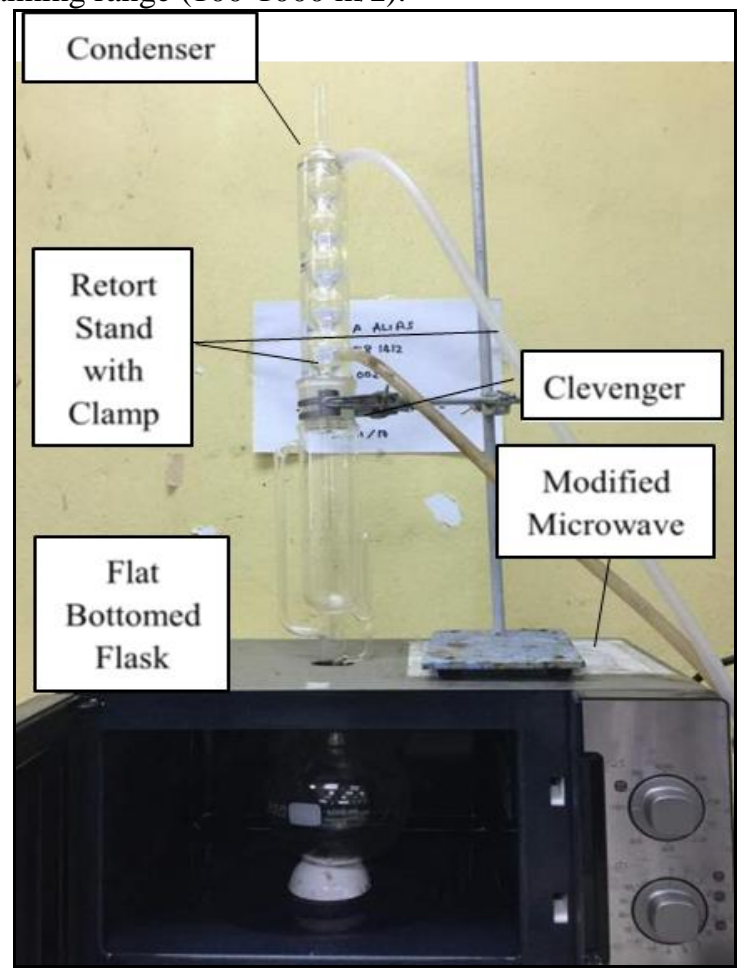

Fig. 1. MAHD set-up
D. Fourier transform infrared transmission (FTIR) analysis

Fourier transform infrared transmission was utilized to recognize functional groups in the patchouli leaf oil. This analysis was carried out to determine the bonding structures present in the essential oil by studying the position of peaks in the IR spectra. The IR spectra were acquired by utilizing an FTIR spectrometer (Nicolet iS5 iD7 ATR; Thermo Scientific, Germany) equipped with OMNIC software. The wavenumber ranging from $4000-500 \mathrm{~cm}-1$ was used to analyze the oil.

\section{E. Nuclear magnetic resonance (NMR)}

$1 \mathrm{H}$ NMR spectra were recorded on a Bruker AMX500 spectrometer operating at $500 \mathrm{MHz}$ for the proton nucleus at room temperature. The patchouli oil samples were used to obtain 1H NMR spectra with the following acquisition parameters: Acquisition time $3.75 \mathrm{~s}, 16$ scans, $10 \mathrm{~s} \mathrm{D1}$ spectral width $4370.63 \mathrm{~Hz}$, and FID resolution $0.133 \mathrm{~Hz}$. Phase correction and baseline correction were manually performed.

\section{RESULTS AND DISCUSSIONS}

\section{A. Identified chemical compounds through GC-MS analysis}

Patchouli essential oil was analyzed using gas chromatography-mass spectrometry (GC-MS) to identify the chemical compounds in the oil (Table 1). A total number of twenty-nine chemical compounds were identified. The oil reflected about $60.25 \%$ non-oxygenated and $39.49 \%$ 
Table 1 List of chemical compounds in patchouli essential oil using GC-MS analysis

\begin{tabular}{|c|c|c|c|}
\hline Number & Compounds & $\begin{array}{c}\text { Molecular } \\
\text { Formula }\end{array}$ & $\begin{array}{l}\text { Mass percentage of } \\
\text { chemical compounds in } \\
\text { crude extracted }(\%)\end{array}$ \\
\hline \multicolumn{4}{|c|}{ Oxygenated Terpenes } \\
\hline 1 & Patchouli alcohol & $\mathrm{C}_{15} \mathrm{H}_{26} \mathrm{O}$ & 26.25 \\
\hline 3 & Aristol-9-en-8-one & $\mathrm{C}_{15} \mathrm{H}_{22} \mathrm{O}$ & 1.61 \\
\hline 4 & Cashmeran & $\mathrm{C}_{14} \mathrm{H}_{22} \mathrm{O}$ & 1.49 \\
\hline 5 & Ethyl chrysanthemate & $\mathrm{C}_{12} \mathrm{H}_{20} \mathrm{O}_{2}$ & 0.83 \\
\hline 6 & $\beta$-Pinone & $\mathrm{C}_{9} \mathrm{H}_{14} \mathrm{O}$ & 0.6 \\
\hline 9 & 2(1H) Naphthalenone, 3,5,6,7,8,8a-hexahydro-4,8a-dimethyl-6-(1-methylethenyl)- & $\mathrm{C}_{15} \mathrm{H}_{22} \mathrm{O}$ & 0.42 \\
\hline 10 & 2-(2-Methylpropylidene)-1H-indene-1,3(2H)-dione & $\mathrm{C}_{13} \mathrm{H}_{12} \mathrm{O}_{2}$ & 0.29 \\
\hline 11 & Corymbolone & $\mathrm{C}_{15} \mathrm{H}_{24} \mathrm{O}_{2}$ & 0.28 \\
\hline 12 & 2-(2-Furyl)-1,3-thiazolidine & $\mathrm{C}_{7} \mathrm{H}_{9} \mathrm{NOS}$ & 0.11 \\
\hline 13 & 2-Ethylphenol & $\mathrm{C}_{8} \mathrm{H}_{10} \mathrm{O}$ & nd \\
\hline 14 & 3,4-Dimethyl-3-cyclohexene-1-carboxaldehyde & $\mathrm{C}_{9} \mathrm{H}_{14} \mathrm{O}$ & nd \\
\hline 15 & 4-Fluoro-3-nitrotoluene & $\mathrm{C}_{7} \mathrm{H}_{6} \mathrm{FNO}_{2}$ & nd \\
\hline 20 & $\beta$-Patchoulene & $\mathrm{C}_{15} \mathrm{H}_{24}$ & 9.57 \\
\hline 21 & Aromandendrene & $\mathrm{C}_{15} \mathrm{H}_{24}$ & 3.61 \\
\hline 22 & Patchoulene & $\mathrm{C}_{15} \mathrm{H}_{24}$ & 2.96 \\
\hline 23 & Dehydroaromadendrene & $\mathrm{C}_{15} \mathrm{H}_{22}$ & 1.65 \\
\hline 24 & Caryophyllene & $\mathrm{C}_{15} \mathrm{H}_{24}$ & 1.43 \\
\hline 25 & Longifolene & $\mathrm{C}_{15} \mathrm{H}_{24}$ & 1.23 \\
\hline 26 & alpha-guaiene & $\mathrm{C}_{15} \mathrm{H}_{24}$ & 0.61 \\
\hline 27 & Guaiazulene & $\mathrm{C}_{15} \mathrm{H}_{18}$ & 0.47 \\
\hline 28 & o-Xylene & $\mathrm{C}_{8} \mathrm{H}_{10}$ & 0.39 \\
\hline 29 & m-Xylene & $\mathrm{C}_{8} \mathrm{H}_{10}$ & 0.36 \\
\hline 30 & Cyclopentane-3'-spirotricyclo $[3 \cdot 1 \cdot 0.0(2,4)]$ hexane-6'-spirocyclopentane & $\mathrm{C}_{14} \mathrm{H}_{20}$ & 0.33 \\
\hline 31 & 3,4-Dimethylstyrene & $\mathrm{C}_{10} \mathrm{H}_{12}$ & 0.16 \\
\hline 32 & Naphthalene, 6-butyl-1,2,3,4-tetrahydro- & $\mathrm{C}_{14} \mathrm{H}_{20}$ & 0.05 \\
\hline 33 & $\gamma$-Gurjunene & $\mathrm{C}_{15} \mathrm{H}_{24}$ & nd \\
\hline 42 & alpha-Himachalene & $\mathrm{C}_{15} \mathrm{H}_{24}$ & nd \\
\hline 43 & 1,4-Dimethyladamantane & $\mathrm{C}_{12} \mathrm{H}_{20}$ & 0.52 \\
\hline \multirow{3}{*}{\multicolumn{3}{|c|}{$\begin{array}{l}\text { Total non-oxygenated } \\
\text { Total oxygenated com } \\
\text { Total identified }(\%)\end{array}$}} & 60.25 \\
\hline & & & 39.49 \\
\hline & & & 99.74 \\
\hline
\end{tabular}


Table 2 Phenolic compounds in patchouli leaf oil

\begin{tabular}{|c|c|c|c|c|c|c|c|}
\hline No. & $\begin{array}{c}\text { Observed RT } \\
(\min )\end{array}$ & Component name & Chemical formula & Observed $(\mathrm{m} / \mathrm{z})$ & Response & Adducts & $\begin{array}{c}\text { Total fragment } \\
\text { found }\end{array}$ \\
\hline 1 & 5.42 & Tellimagrandin II & $\mathrm{C} 41 \mathrm{H} 30 \mathrm{O} 26$ & 983.1007 & 4645 & $+\mathrm{HCOO}$ & 23 \\
\hline 2 & 5.53 & Pedunculagin & $\mathrm{C} 34 \mathrm{H} 24 \mathrm{O} 22$ & 783.0700 & 3582 & $-\mathrm{H}$ & 41 \\
\hline 3 & 7.29 & Furosin & $\mathrm{C} 27 \mathrm{H} 22 \mathrm{O} 19$ & 695.0756 & 4773 & $+\mathrm{HCOO}$ & 71 \\
\hline 4 & 5.82 & Kukoamine A & $\mathrm{C} 28 \mathrm{H} 42 \mathrm{~N} 4 \mathrm{O} 6$ & 529.3018 & 4237 & $-\mathrm{H}$ & 11 \\
\hline 5 & 6.02 & $\begin{array}{l}1,2,3,4,6 \text {-Penta-O'Galloyl- } \\
\beta \text {-D'Glucopyranoside }\end{array}$ & $\mathrm{C} 41 \mathrm{H} 32 \mathrm{O} 26$ & 985.1175 & 7074 & $+\mathrm{HCOO}$ & 21 \\
\hline 6 & 6.57 & Geraniin & $\mathrm{C} 41 \mathrm{H} 28 \mathrm{O} 27$ & 951.0737 & 5234 & $-\mathrm{H}$ & 55 \\
\hline 7 & 6.64 & Casuarinin & $\mathrm{C} 41 \mathrm{H} 28 \mathrm{O} 26$ & 981.0840 & 4895 & $+\mathrm{HCOO}$ & 28 \\
\hline 8 & 6.84 & Terchebin & $\mathrm{C} 41 \mathrm{H} 30 \mathrm{O} 27$ & 953.0916 & 4723 & $-\mathrm{H}$ & 64 \\
\hline 9 & 7.69 & Mallotinic acid & $\mathrm{C} 34 \mathrm{H} 26 \mathrm{O} 22$ & 831.0899 & 3684 & $+\mathrm{HCOO}$ & 46 \\
\hline 10 & 0.51 & Schizonepetoside E & $\mathrm{C} 16 \mathrm{H} 28 \mathrm{O} 8$ & 349.1838 & 428455 & $+\mathrm{H}$ & 7 \\
\hline 11 & 1.45 & Xanthumin & $\mathrm{C} 17 \mathrm{H} 22 \mathrm{O} 5$ & 307.1520 & 5614 & $+\mathrm{H}$ & 0 \\
\hline 12 & 3.89 & Sonchuside A & $\mathrm{C} 21 \mathrm{H} 32 \mathrm{O} 8$ & 435.1989 & 176863 & $+\mathrm{Na},+\mathrm{K}$ & 34 \\
\hline 13 & 4.41 & Hookeroside C & $\mathrm{C} 38 \mathrm{H} 62 \mathrm{O} 15$ & 781.3982 & 110716 & $+\mathrm{Na}$ & 16 \\
\hline 14 & 5.45 & 2-Hydroxyesculentic acid & $\mathrm{C} 30 \mathrm{H} 46 \mathrm{O} 7$ & 541.3127 & 290124 & $+\mathrm{Na}$ & 48 \\
\hline 15 & 6.13 & 11-Oxo-kansenonol & $\mathrm{C} 30 \mathrm{H} 46 \mathrm{O} 4$ & 493.3288 & 813628 & $+\mathrm{Na}$ & 30 \\
\hline 16 & 7.02 & Akebonoic acid & $\mathrm{C} 29 \mathrm{H} 44 \mathrm{O} 3$ & 463.3179 & 420054 & $+\mathrm{Na}$ & 30 \\
\hline 17 & 7.51 & $\begin{array}{l}\text { 3a,30-Dihydroxylup-20 } \\
\text { (29)-en-27-oic acid }\end{array}$ & $\mathrm{C} 30 \mathrm{H} 48 \mathrm{O} 4$ & 495.3443 & 73459 & $+\mathrm{Na}$ & 19 \\
\hline 18 & 3.28 & 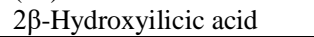 & $\mathrm{C} 15 \mathrm{H} 24 \mathrm{O} 4$ & 291.1569 & 77053 & $+\mathrm{Na}$ & 5 \\
\hline
\end{tabular}

oxygenated compounds. This is because the heat transfer in MAHD is generated from the oil gland to the surrounding solvent [9]. Hence, the maximum quantity of essential oil can be extracted from patchouli oil gland using MAHD. Patchoulol is the main oxygenated compound extracted from patchouli leaves. Moreover, the higher the number of oxygenated compounds, the higher the quality of essential oil. MAHD method shows higher probability in the production of natural aroma of the patchouli oil.

\section{B. Identified chemical compounds through LC-Q-TOF-MS analysis}

The phenolic compounds in the patchouli leaf oil were analyzed using LC-Q-TOF-MS. A total of 18 phenolic compounds were identified as shown in Table 2. Tannins, phenolic alkaloids, flavonoids, sesquiterpenoids lactones, and triterpenoids are the phenolic compounds found in the patchouli oil. From the identified compounds, eight chemical compounds are tannins. Tannins are the complex mixture of polyphenol which can act as an antioxidant [10], anti-inflammatory [11] and anti-microbial [12]. However, $1,2,3,4,6$-Penta-O' galloyl- $\beta$-D'glucopyranoside is a compound reported to possess anti-cancer [13] and antitumor effects [14]. Geraniin has good radical scavenging activity [15] while Casuarinin possesses anti-oxidant properties that could inhibit the growth of T24 bladder cancer cells [15]. Moreover, Kukoamine A is a phenolic alkaloid reported to possesses natural anti-oxidant properties with mechanisms involving free radical scavenging [15]. Other pharmaceutical effects such as antihypertension, anti-analgesic, anti-inflammatory, antisepsis, and enhancing autoimmune still abound [16].

\section{Identified chemical compounds through FTIR analysis}

Fig. 2 illustrated the FTIR spectra for patchouli oil obtained from MAHD method. The infrared spectroscopy (IR) characteristics fingerprint peaks for patchouli oil falls within the range of $3400-800 \mathrm{~cm}-1$. These spectra show that there is an overlap of the absorption spectrum of different components in the oil because patchouli essential oil is a complex mixture of volatile oils [17]. There are some observable peaks from MAHD spectrum. The peak at 3313 $\mathrm{cm}-1$ represents $\mathrm{O}-\mathrm{H}$ stretching in alcohol [18] which shows the abundance of patchoulol, an important material in perfumery. Another observable peak at $1635 \mathrm{~cm}-1$ corresponds to $\mathrm{C}=\mathrm{O}$ stretching vibration of carbonyl aldehyde [17]. It proves that patchouli oil contains higher amounts of aldehyde compounds. The peak at $1445 \mathrm{~cm}-1$ can be attributed to $\mathrm{C}-\mathrm{H}$ bending stretching in alkane [19] and $\mathrm{C}=\mathrm{C}$ stretching from aromatic rings while the peak at $1373 \mathrm{~cm}-1$ is a characteristic of $\mathrm{O}-\mathrm{H}$ bending in a carboxylic acid [18]. The peak at $886 \mathrm{~cm}-1$ is a representation of $\mathrm{C}-\mathrm{H}$ bending vibration [17]. Summary of major peaks and their representation are listed in Table 3. From Table 3, five functional groups were identified from the MAHD spectrum.

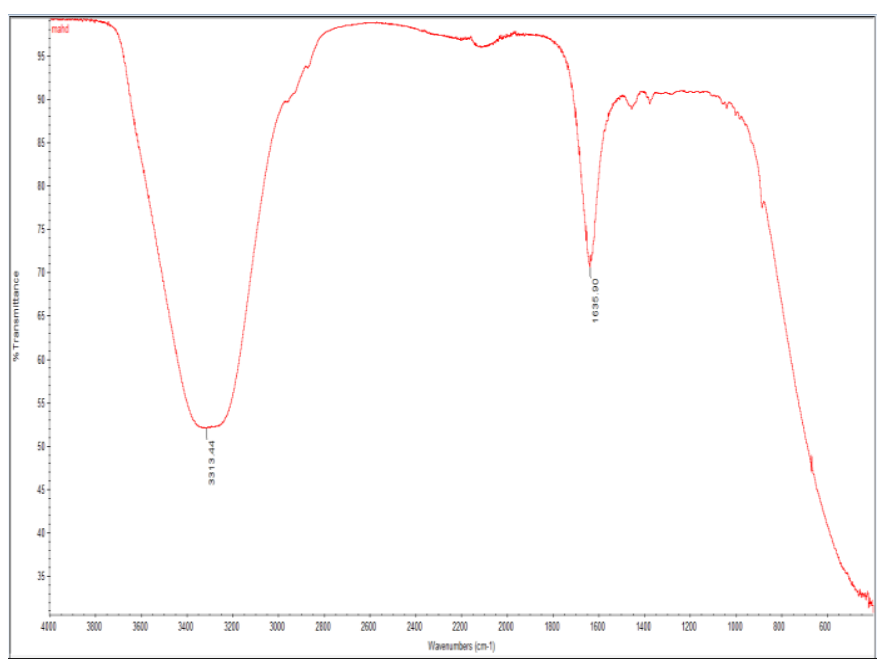

Fig. 2. FTIR spectrum 
Table 3 Summary of important peaks and their representation

\begin{tabular}{lc}
\hline Functional group representation & Position of bands $\left(\mathbf{c m}^{-\mathbf{1}}\right)$ \\
\hline C-H bending vibration & 886 \\
O-H bending & 1373 \\
$\begin{array}{l}\text { C-H bending stretching alkane and C=C } \\
\text { stretching aromatic }\end{array}$ & 1445 \\
$\begin{array}{l}\text { C=O stretching vibration and N-H } \\
\text { bending }\end{array}$ & 1635 \\
O-H stretching & 3313 \\
\end{tabular}

\section{Identified chemical compounds through NMR analysis}

The representative one-dimensional $1 \mathrm{H}$ NMR spectra of patchouli leaf oil are shown in Fig. 3. The vertical scale B was magnified for better visibility. Table 4 shows the chemical shifts from both NMR spectrum A and B with their protons. The chemical shift at $0 \mathrm{ppm}$ is the reference point. The highest peak in the NMR spectrum A which is at $4.4543 \mathrm{ppm}$ represents the alcohol group [20]. This proves the abundance of patchouli alcohol in patchouli leaves extract which contributes to the aroma of patchouli essential oil [21]. The peak of $8.0 \mathrm{ppm}$ is characterized by the signals of aryl group (patchoulene, azulene and valencene) which play an important role in aroma [20]; [22] and act as antiinflammatory [23], anti-ulcer [23]; [24], and anti-diabetic [24].

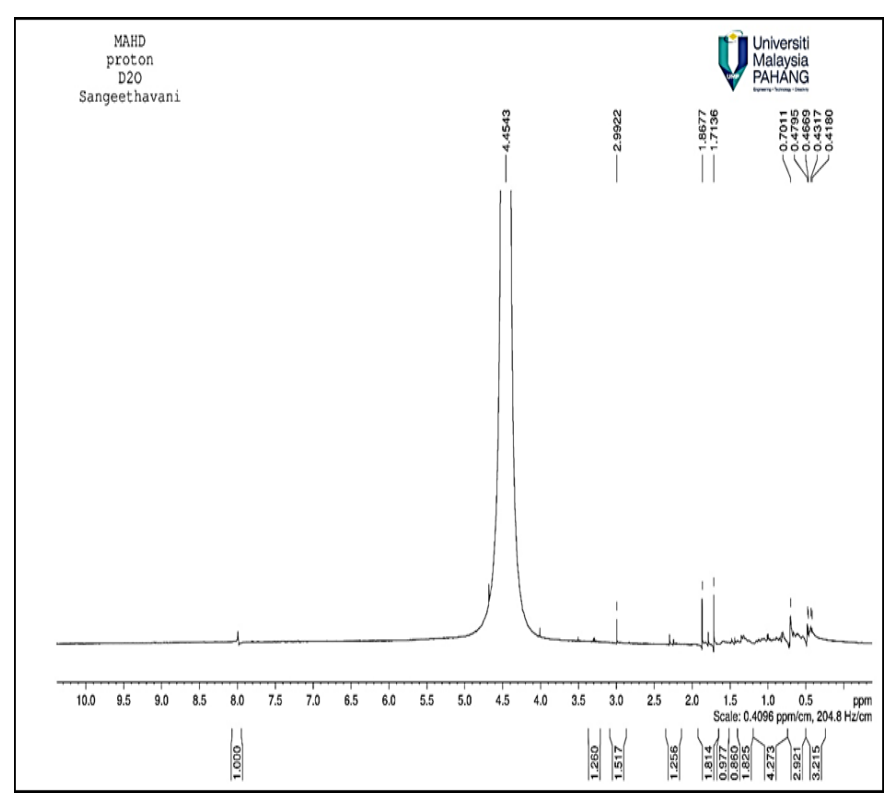

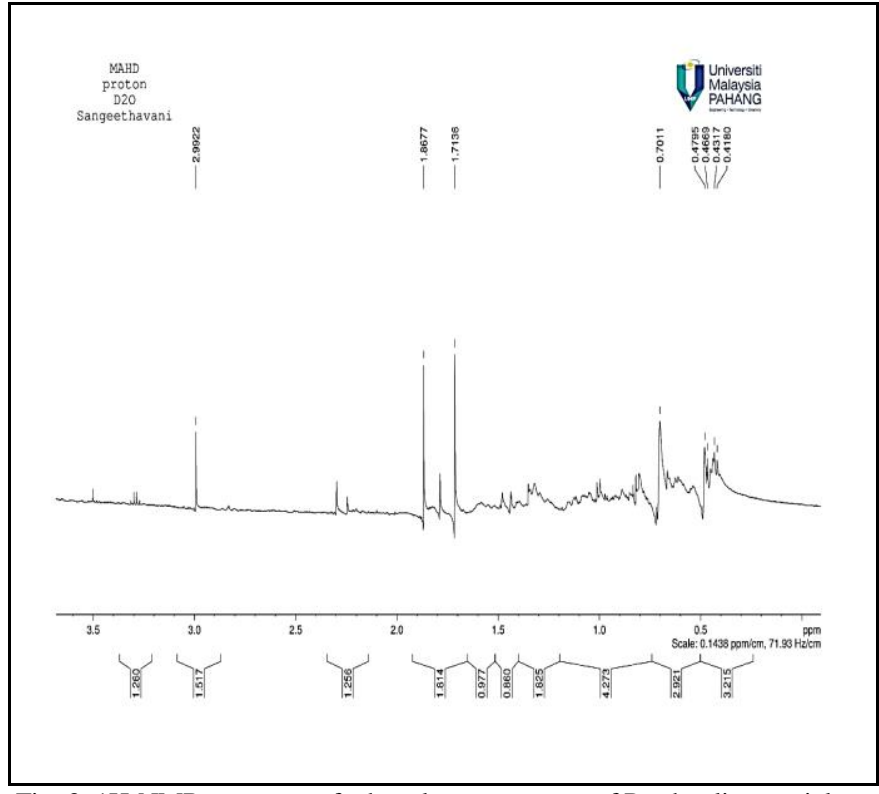

Fig. 3. 1H-NMR spectrum of ethanol-water extract of Patchouli essential oil. Vertical scale in B is magnified with respect to A.

Table 4 The chemical shifts with their protons

\begin{tabular}{cc}
\hline Chemical Shift, $\boldsymbol{\delta}(\mathbf{p p m})$ & Protons \\
\hline $\mathbf{0 . 7 0 1 1}$ & $\mathrm{R}-\mathrm{CH}_{3}$ \\
& \\
1.7136 & $\mathrm{R} 3 \mathrm{C}-\mathrm{CH}$ \\
1.8677 & $=\mathrm{C}-\mathrm{CH}$ \\
2.9922 & $-\mathrm{C} \equiv \mathrm{C}-\mathrm{H}$ \\
4.4543 & $\mathrm{HC}-\mathrm{OH}$ \\
8.0 & $\mathrm{Ar}-\mathrm{H}$ \\
\hline
\end{tabular}

\section{CONCLUSION}

This study has successfully characterized the oil obtained from patchouli leaves through MAHD using GCMS, LC-QTOF-MS, FTIR, and NMR. The obtained results have clearly indicated that the oil possessed about $60.25 \%$ non-oxygenated and $39.49 \%$ oxygenated compounds through GC-MS analysis; the LC-Q-TOF-MS results showed that the oil comprised 18 phenolic compounds which are majorly tannins, phenolic alkaloids, flavonoids, sesquiterpenoids lactones, and triterpenoids. Additionally, there was the presence of $\mathrm{O}-\mathrm{H}$ stretching in alcohol indicating the abundance of patchoulol, $\mathrm{C}=\mathrm{O}$ stretching vibration of carbonyl aldehyde showing that the patchouli oil contains higher amounts of aldehyde compounds, $\mathrm{C}-\mathrm{H}$ bending stretching of alkane, and $\mathrm{C}=\mathrm{C}$ stretching from aromatic rings. The NMR results indicated that the abundance of patchouli alcohol in the oil which can be contributed to the aroma. Thus, patchouli leaf oil is an important plant that is endowed with varieties of chemical compounds. 


\section{REFERENCES}

[1] Kusuma HS, Mahfud M (2017) Microwave-assisted hydrodistillation for extraction of essential oil from patchouli (Pogostemon cablin) leaves. Periodica Polytech Chem Eng 61:8292.

[2] Sundaresan V, Singh SP, Mishra AN, Shasany AK, Darokar MP, Kalra A, Naqvi AA (2009) Composition and comparison of essential oils of Pogostemon cablin (Blanco) Benth. (Patchouli) and Pogostemon travancoricus Bedd. var. travancoricus. J Essent Oil Res 21:220-222.

[3] Buré CM, Sellier NM (2004) Analysis of the essential oil of Indonesian patchouli (Pogostemon cabin Benth.) using GC/MS (EI/CI). J Essent Oil Res 16:17-19.

[4] Donelian A, Carlson LHC, Lopes TJ, Machado RAF (2009) Comparison of extraction of patchouli (Pogostemon cablin) essential oil with supercritical CO2 and by steam distillation. J Supercrit Fluid 48:15-20.

[5] Kusuma HS, Altway A, Mahfud M (2018) Solvent-free microwave extraction of essential oil from dried patchouli (Pogostemon cablin Benth) leaves. J Ind Eng chem 58:343-348

[6] Deguerry F, Pastore L, Wu S, Clark A, Chappell J, Schalk M (2006) The diverse sesquiterpene profile of patchouli, Pogostemon cablin, is correlated with a limited number of sesquiterpene synthases. Arch Biochem Biophys 454:123-136.

7] Alara OR Abdurahman NH (2018) Kinetics studies on effects of extraction techniques on bioactive compounds from Vernonia cinerea leaf. J Food Sci Tech.

[8] Tsubaki N, Nishimura K, Hirose Y (1967). Hydrocarbons in patchouli oil. Bull Chem Soc Jpn 40:597-600.

[9] Jeyaratanam N, Nour AH, Kanthasamy R, Nour AH, Yuvaraj AR, Akindoyo JO (2016) Essential oil from Cinnamomum cassia bark through hydrodistillation and advanced microwave assisted hydrodistillation. Ind Crop Prod 92:57-66.

[10] Owolabi OO, James DB, Sani I, Andongma BT, Fasanya OO, Kure B (2018) Phytochemical analysis, antioxidant and anti-inflammatory potential of Feretia apodanthera root bark extracts. BMC Complem Altern M 18:12.

[11] Minhas AM, Khan AU, Miana GA (2018) Anti-inflammatory actions of Berberis lycium (whole plant) in acute and chronic models of inflammation in mice. J Anim Plant Sci 28:754-760.

[12] Abubaka HMG, Usman H, Karumi Y (2018) Evaluation of antimicrobial activity and phytochemical composition of some fractions of methanol stem bark extract of Diospyros mespiliformis. Bayero J Pure Appl Sci 11:47-51
[13] Kawk SH, Kang YR, Kim YH (2018) 1, 2, 3, 4, 6-Penta-O-galloyl$\beta$-d-glucose suppresses colon cancer through induction of tumor suppressor. Bioorganic med chem lett 28:2117-2123.

[14] Sekowski S, Bitiucki M, Ionov M, Zdeb M, Abdulladjanova N, Rakhimov R, Zamaraeva M (2018) Influence of valoneoyl groups on the interactions between Euphorbia tannins and human serum albumin. J Lumin 194:170-178

[15] Li K, Zeng M, Li Q, Zhou B (2018) Identification of polyphenolic composition in the fruits of Rubus chingii $\mathrm{Hu}$ and its antioxidant and antiproliferative activity on human bladder cancer T24 cells. J Food Meas Charact 1-10.

[16] Liu J, Jiang X, Zhang Q, Lin S, Zhu J, Zhang Y, Zhao Q (2017) Neuroprotective effects of Kukoamine A against cerebral ischemia via antioxidant and inactivation of apoptosis pathway. Neurochem Int 107:191-197.

[17] Li YQ, Kong DX, Wu H (2013) Analysis and evaluation of essential oil components of cinnamon barks using GC-MS and FTIR spectroscopy. Ind Crop Product 41:269-278.

[18] Hosseini SF, Zandi M, Rezaei M, Farahmandghavi F (2013) Twostep method for encapsulation of oregano essential oil in chitosan nanoparticles: Preparation, characterization and in vitro release study. Carbohydr Polym 95:50-56.

[19] Wen P, Zhu DH, Wu H, Zong MH, Jing YR, Han SY (2016) Encapsulation of cinnamon essential oil in electrospun nanofibrous film for active food packaging. Food Control 59:366-376

[20] Mullen CA, Strahan GD, Boateng AA (2009) Characterization of various fast-pyrolysis bio-oils by NMR spectroscopy. Energy Fuels 23:2707-271

[21] Fan L, Jin R, Liu Y, An M, Chen S (2011) Enhanced extraction of patchouli alcohol from Pogostemon cablin by microwave radiationaccelerated ionic liquid pretreatment. J Chrom B, 879:3653-3657.

[22] Sales A, Paulino BN, Pastore GM, Bicas JL (2018) Biogeneration of aroma compounds. Curr Opin Food Sci 19:77-84

[23] Wu JZ, Liu YH, Liang JL, Huang QH, Dou YX, Nie J, Wu QD (2018) Protective role of $\beta$ - patchoulene from Pogostemon cablin against indomethacin-induced gastric ulcer in rats: Involvement of anti-inflammation and angiogenesis. Phytomedicine 39:111-118.

[24] Leino TO, Turku A, Yli-Kauhaluoma J, Kukkonen JP, Xhaard H, Wallén EA (2018) Azulene- based compounds for targeting orexin receptors. Eur J Med Chem 157:88-100. 